\title{
When goals do not concur: conflicting perceptions of school science
}

\author{
David Fortus ${ }^{*}$ and Limor Daphna
}

\begin{abstract}
In this case study we investigated how differences in the achievement goal orientations of a high school biology teacher and her 9th grade (14 years old) student led to tensions between them in their perspectives of what it meant to do school science, leading the teacher to under-estimate the student and recommend that she abandon further studies in biology. During 9th grade, Israeli students decide upon their preferred subject of emphasis for the rest of high school. The student wanted to major in biology but the teacher felt it was beyond her abilities. While expectancy-value theory is typically used to explain the mechanism through which under-estimation can lead to a lower sense of self-efficacy and lower performance, the reasons why a science teacher may under-estimate a student have yet to be studied. We analyze both the student and the teacher's motives and learn that unforeseen obstacles may lie on a student's road to science.
\end{abstract}

Keywords: Achievement goals orientation, Motivation, Choice, Under-estimation, Elective courses

\section{Introduction}

When they are in 9th grade (14 years old for most children), Israeli students have to reach an important decision concerning their academic future: they must choose in which subject(s) they wish to major. At the end of 12th grade, all students take matriculation exams in their major(s), as well as in other compulsory subjects, such as Hebrew, literature, history, English, mathematics, etc. In most high schools, students can choose between several subjects in the humanities, arts and sciences in which to major. In the "Ben-Gurion" high school (a pseudonym), students are permitted to major in two different subjects. Certain eligibility requirements must be met as a condition of acceptance to one of the science study paths, giving these the reputation of being more prestigious and more difficult than the others.

Throughout Israel and over the past decade, less than $40 \%$ of students have chosen to major in any of the sciences (Israel Central Bureau of Statistics, 2012), despite the prominence and financial security offered by science

\footnotetext{
* Correspondence: David.fortus@weizmann.ac.il

Department of Science Teaching, Weizmann Institute of Science, Rehovot, Israel
}

and technology-related professions in this country. Israel's economy is largely driven by its hi-tech industry and there is a continuous and constant need for more scientists and engineers, with new companies continually being established while existing ones expand.

How many capable students are there, who, had they be given the opportunity by their teachers, would have chosen to major in science? This study presents the case of a single student and her biology teacher whose differing goal orientations led to tensions between them, leading the teacher to recommend that the student major in another subject, not in biology. We believe there are lessons to be learned from this case that are relevant to all teachers, not just science teachers.

\section{Students' declining motivation to engage with science} One of the main theories advanced for reaching an understanding of students' academic motivation is achievement goal orientation theory (Ames, 1992), which distinguishes between mastery goals, which indicate the desire to develop competence and understanding, and performance goals, which indicate the desire to demonstrate competence and understanding. Performance goals are often divided into two valences, performance-
Springer Open

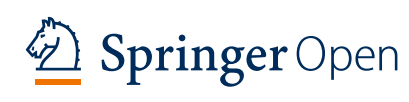

(c) The Author(s). 2020 Open Access This article is licensed under a Creative Commons Attribution 4.0 International License, which permits use, sharing, adaptation, distribution and reproduction in any medium or format, as long as you give appropriate credit to the original author(s) and the source, provide a link to the Creative Commons licence, and indicate if changes were made. The images or other third party material in this article are included in the article's Creative Commons licence, unless indicated otherwise in a credit line to the material. If material is not included in the article's Creative Commons licence and your intended use is not permitted by statutory regulation or exceeds the permitted use, you will need to obtain permission directly from the copyright holder. To view a copy of this licence, visit http://creativecommons.org/licenses/by/4.0/. 
approach and performance-avoidance. Performanceavoidance goals involve the fear of being perceived as unknowing and incompetent by others while performanceapproach goals fit the foregoing description. Mastery goals have also been divided into two similar valences, masteryapproach and mastery-avoidance. The theoretical distinction between mastery goals' two valences is ignored in this study as it appears that the mastery-avoidance construct is not reliably identified by adolescents (Zepeda, Richey, Ronevich, \& Nokes-Malach, 2015). Using an achievement goals orientation perspective, it has been demonstrated that adolescents' mastery goal orientation toward science typically declines as they mature from elementary school to middle school (Senko, Hulleman, \& Harackiewicz, 2011; Vedder-Weiss \& Fortus, 2011). This is significant because mastery goal orientation is an important predictor of classroom engagement and continuing motivation for science (Fortus \& Vedder-Weiss, 2014; Meece, Blumenfeld, \& Hoyle, 1988; Vedder-Weiss \& Fortus, 2013). Several environmental factors are related to students' mastery orientations: students' peers, science teachers, parents, and general school culture (Ames, 1992; Basu \& Barton, 2007; VedderWeiss \& Fortus, 2013). Studies have shown that as students mature, their science teachers play an ever larger role, often becoming the single most important environmental factor in determining students' motivation to engage with science (Vedder-Weiss \& Fortus, 2013). Science teachers, of course, have their own instructional goals (Meis Friedrichsen \& Dana, 2005), and students' perceptions of these goals and instructional practices can be associated with students' personal goal orientations (Friedel, Cortina, Turner, \& Midgley, 2007; Vedder-Weiss \& Fortus, 2013).

Other than emphasizing mastery goals, another way in which science teachers can influence students' choices and motivation to engage with science is by strengthening or weakening their belief in their ability to succeed in science (Beghetto, 2007; Usher \& Pajares, 2008), which, as previously indicated, is reputed in some schools to be more challenging than other subjects.

Self-efficacy is the belief in one's ability to successfully perform a task; it is related to one's goals orientation and is a significant predictor of academic outcomes (Bandura, 1993; Pajares \& Graham, 1999). According to Bandura (1993), a person's sense of self-efficacy derives from four sources: previous accomplishments, vicarious experiences, physiological and emotional states, and social persuasion. Previous accomplishments refer to the individual's history of success, on which the feeling that the individual is indeed capable of being successful is based. Vicarious experience refers to the availability of successful individuals, with whom the individual can identify, leading her to believe that she too can be successful. Physiological and emotional states influence our self-efficacy. We usually feel more self-efficacious when we are calm than when we are aroused and distressed. Social persuasion is "a way of strengthening people's beliefs that they have what it takes to succeed" (Bandura, 1994, p. 72). Social persuasion can provide a boost in perceived ability. When it is effective in mobilizing a person to action, and his or her actions lead to success, enhanced self-efficacy may become more permanent.

Social persuasion can be both positive and negative (Koballa, 1992). Consider the following example: Rosenthal and Jacobson (1968) administered an IQ test and a "capability" exam to elementary school students. The fabricated results of this "capability" exam were given to the students' teachers and showed that $20 \%$ of the students, who were randomly chosen from the total student population, were "likely to exhibit a high intellectual level as well as a great amount of progress during the upcoming school year." No information of any kind was provided regarding the other $80 \%$ of the students. At the end of the school year the interviewers readministered the Intelligence Quotient (IQ) test and compared its scores to those of the beginning of the year. The result was that the students who belonged to the positive expectations group showed a higher gain in their intelligence scores than the students who belonged to the no feedback group.

\section{The Pygmalion effect and the golem effect}

Rosenthal and Jacobson named the phenomenon, whereby students grasp and fulfill their teachers' expectations of them, the Pygmalion effect. Babad, Inbar, and Rosenthal (1982) extended the research on the Pygmalion effect and showed that negative expectations also lead to self-fulfilling results: students who receive implicit messages of lack of faith in their ability become the low achievers their teachers expected them to be. This reverse phenomenon is called, in accordance with the Jewish myth, the Golem effect. The Golem effect is traditionally explained as an outcome of expectancy-value theory (Eccles et al., 1983; Eden, 1986): people are likely to engage in activities only to the extent that they believe is required for them to succeed; if low expectations are set by the teacher, self-efficacy falls, less effort is expended and as a result lower performance is exhibited, justifying the low expectations set by the teacher.

Since the initial studies by Rosenthal and Jacobson, the Pygmalion Effect has been widely studied (e.g., Jamieson, Lydon, Stewart, \& Zanna, 1987; Murphy, Campbell, \& Garavan, 1999); on the other hand, there remains a paucity of research on the Golem effect, primarily due to ethical concerns that invoking the Golem effect can lead to negative expectancies in students and lower performance (Reynolds, 2007). Published examples of the Golem effect in K-12 schools are extremely rare. 
While the mechanism underlying the Golem effect is explained using expectancy-value theory, this theory does not address the issue of what leads an individual (in our case, a science teacher) to under-estimate another individual (in our case, a student) or why an individual may be able to withstand the negative influence of the under-estimation. Using the perspective of achievement goal orientation theory, we hope to shed some light on this in this study.

\section{Research focus}

This case study investigated how a biology teacher and her student's differing achievement goal orientations led to tensions between them about what it meant to do school science and to incongruence between the actual abilities of the student and the way she was appraised by the teacher. The research question for this study is: How can different goal orientations lead to tensions between a biology teacher and her student?

\section{Methodology and methods}

This case study is presented as a narrative inquiry which is a methodology for studying lived experiences (Clandinin, 2006; Connelly \& Clandinin, 1990). It draws on field notes of shared experiences, stories, recorded conversations, interviews, and quantitative data from written surveys so as to reach an understanding of how the participants created meaning in their lives. All interviews and classroom observations were naturalistic (Stake, 1995). As will be clarified in the following section, this study did not begin as a case study, but rather it emerged during the process of collecting data for a larger quantitative study, and thus, some of the data used in this case study originates in the quantitative study, leading to a mixing of research methods. The quantitative data is used describe one student's goal orientation in science in relation to those of her classmates and to identify changes to her goal orientation in science that occurred during the study. The narrative's plot and focus was redefined multiple times while collecting and analyzing the data; the foci of the interviews were re-tuned respectively as the goal of the study developed. The final results are presented as a personal narrative of one of the authors (L.D.) interspersed with theory-driven reflections (Thody, 2006).

\section{Participants}

The participants in this study were:

(1) Sharon (pseudonym), a biology teacher at the "Ben-Gurion" high-school (pseudonym).

(2) Neta (pseudonym), a 9th grade student who studied biology in one of Sharon's classes.

(3) Eighty-six additional students from Sharon's three 9th grade biology classes - 41 girls and 45 boys.
Ben-Gurion high school is located in central Israel, south of Tel Aviv. It was chosen as the research site due to its proximity to the research institute where both authors work. Sharon, the teacher, volunteered to participate in this study; she felt that involvement in research would enable her to improve her teaching.

\section{Research process}

The study took place throughout the entire 2012-2013 school year. Figure 1 shows a timeline of the study.

After receiving Institutional Review Board (IRB) approval, at the Initial contact, one of the authors (L.D.) joined Sharon's classes as an observer equipped with a tape-recorder and a diary for recording field-notes. After being introduced to the students by Sharon as a researcher interested in motivation to study science, the students were given an IRB-approved form that described the purposes of the study and were requested to obtain their parents' signed permission to participate in this study (all but one of the students obtained parental permission).

About 2 weeks later a motivation and science identity survey was conducted. The survey was conducted during regular biology classes. The students were told that all their answers would be confidential and that it was not compulsory to answer any of the questions.

Following the survey, which gave a general affective mapping of the participants, L.D. interviewed 38 of the student-participants who were chosen because (a) they displayed a range of motivations to study science on the affective survey, (b) classroom observations had identified them as articulate and candid, and (c) they stated an interest in participating in the study. The interviews dealt with the students' relations to their teachers, the students' identities, reputations, aspirations and dreams, their strengths and weaknesses.

Approximately 30 observations were made in Sharon's classes during the first half of the school year. Six additional observations were made during the second half. Seventeen of these observations were audio-recorded and transcribed. In addition, before and after each lesson, L.D. observed the conduct of the students in order to obtain a general impression of their social dynamics. Impromptu testimonies, impressions and feelings that were shared with L.D. by particular students and teachers were either audio-recorded or jotted down in a journal as field notes, as were general school conduct, hall conversations and teachers' faculty room conversations. L.D. would describe her thoughts and questions in the journal as developing after each visit to the school. Whenever data from this journal appears in the findings, it is followed by the word "Journal" in square brackets. 


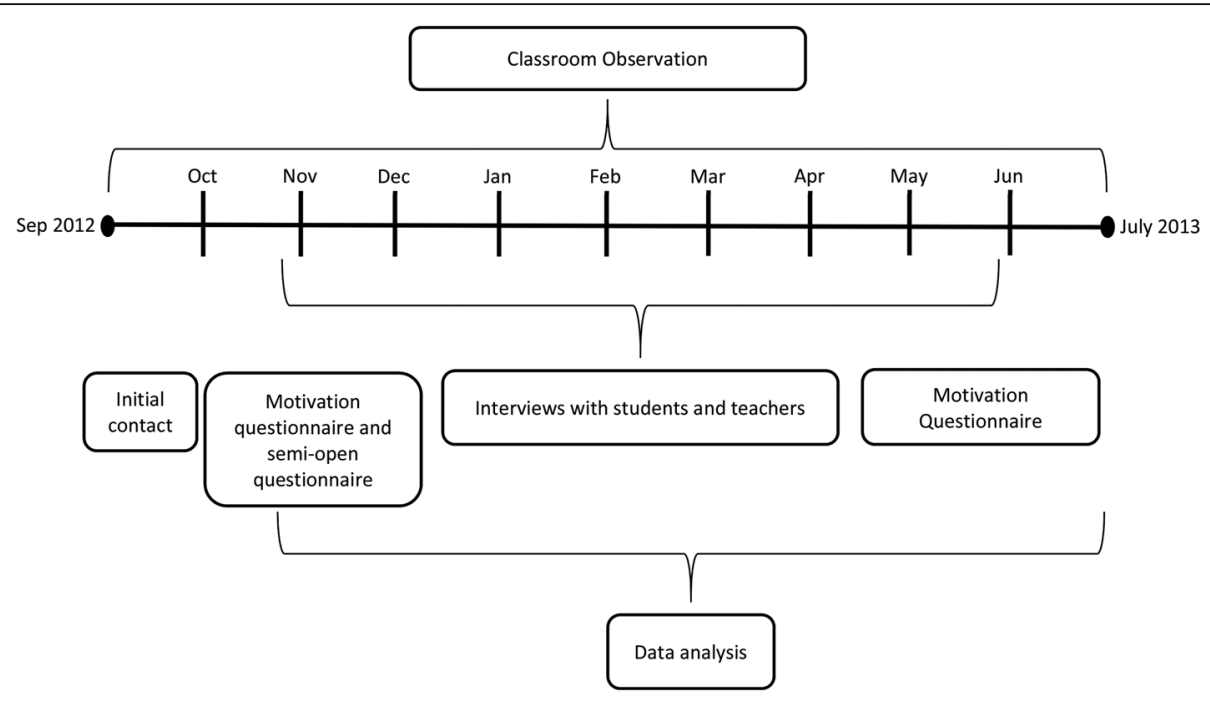

Fig. 1 Study Timeline

However, following these interviews, observations and records-collecting, we felt that the picture being constructed was incomplete. We needed a clearer picture of Sharon's requirements, expectations, and perceptions toward biology as an extended academic high school subject. We also wanted to understand how she experienced her students. To this end, and after explaining to her the need for this additional information, L.D. began interviewing Sharon. At this point, we were confronted with a prominent incongruence between Sharon's perceptions of Neta and Neta's self-perceived abilities and interests. The remainder of the academic year was dedicated to interviewing Sharon and Neta in several semi-formal short interviews ( 5 with Sharon, ranging from 5 to $10 \mathrm{~min}$, and 3 with Neta, ranging from 15 to $25 \mathrm{~min}$ ), 4 coincidental interviews with Sharon, ranging from 3 to $15 \mathrm{~min}, 5$ in-depth lengthy interviews with Sharon, ranging from 30 to $60 \mathrm{~min}$, as well as casual chats before and after class (4 with Sharon, ranging from 2 to 5 min and 6 with Neta, ranging from 2 to $15 \mathrm{~min}$ ).

The last part of the study was dedicated to the analysis and synthesis of the data in order to piece together this narrative.

\section{Data collection \\ Motivation survey}

The motivation survey dealt with students' personal achievement goal orientations, their engagement with science in and out of school, their perceived self-efficacy in various aspects of science and their perceptions of their fellow students', parents', and teachers' goals emphases. Each construct was represented by at least four different items. All items in the survey were based on a
1-5 Likert scale and were drawn from existing validated scales that had been used before with samples from a similar population (Fortus \& Daphna, 2017; Fortus \& Vedder-Weiss, 2014; Vedder-Weiss \& Fortus, 2011, 2013). The complete scales were used unchanged as developed by Vedder-Weiss and Fortus (2012) who also describe their validation. Example items from the different scales are available online in supplement $\mathrm{S} 2$.

\section{Interviews}

The interviews were not identical and followed the students' interests (e.g., "How do you like high school compared to elementary school?", "Have you thought about what you will be when you grow up?", "If you were a science teacher, what kind of teacher would you be?"). Some students were more verbal and more willing to share than the others. Most interviews lasted about $30 \mathrm{~min}$; actual lengths ranged from 20 to $40 \mathrm{~min}$.

\section{Analysis}

To uncover recurring categories, the interviews, classroom and recess observations were first analyzed by coding central and sub-categories (Strauss \& Corbin, 1990). For example: A - questions; A1 - student question; A1.1 - content question. The categories were initially drawn from those used in prior research by VedderWeiss and Fortus (2012) but revised and modified to reflect the nature of the collected data. All categories were reviewed by 3 fellow science education researchers. Controversial categories were discussed and revised until agreement was reached. An example of the categories and sub-categories is provided in online supplement S1. These categories were not used to present the data in 
the findings section but rather to help guide our thinking about the unfolding story.

Four categories regularly recurred: mastery goals orientation, performance goals orientation, asking questions in the classroom, and choosing in which subject to major. Among other prominent categories: self-efficacy, parental support, teacher-student relationship, teacher professionalism.

Using the data from all 86 respondents, the motivation survey was analyzed using SPSS software to calculate means, perform factor analyses, and calculate reliabilities (all scales had Cronbach alphas greater than 0.74). We mapped students' achievement goals orientation, classroom engagement, self-efficacy, and perceptions of their parents, teachers and peers' goals emphases.

\section{Findings}

\section{Introducing the main actors}

Neta, a 9th grade student

I noticed Neta at the very start of my first visit to one of Sharon's 9th grade biology classes. She was smiling, slightly loud, and graceful. The first sentence I heard her say, as I entered the classroom together with Sharon, was: "Sharon, we are so glad you came, we missed you." Sharon replied: "So it's a good thing I came", and together Sharon and I entered the classroom [Journal].

In this first lesson, Neta was not very prominent, and aside from a question or two and a bit of chatter, I didn't think of her as a student who would eventually become the focus this study. The motivation survey indicated that she was highly mastery oriented with a high sense of self-ability. She appeared to be open and articulate [Journal]; thus we added her name to the list of students whom I planned to invite to an interview. When I handed the list of potential interviewees to Sharon, she responded:

Neta Lustig? She is a very weak student. I don't think there is much point in interviewing her. She is not particularly relevant for a study dealing with sciences.

The incongruence between the results of the survey with regards to Neta's self-efficacy in science (she scored 5 out of a maximum of 5 , indicating very high self-efficacy in science), her replies to the open items on the survey, some which are quoted above, and the comment expressed by Sharon surprised us, and thus, I decided to interview Neta nevertheless, in order to investigate the source of this incongruence. Some of the findings from this interview:

Neta was a pleasant teenager, articulate, aware of her surroundings, curious and questioning, sensitive, open... she was quick to share her experiences and hardships with me [Journal]. She shared with me her feelings of loneliness:

Sometimes there are moments in which I feel alone, even if I am not alone, I feel alone. But it is only for a few moments, it is really momentary, and after sometime, it passes...

Reflection on her self-conduct:

A good teacher puts the students in their place; I am fond of this dictatorship, because without it, I don't behave decently.

Reflection on Sharon in the classroom:

Sharon gives a feeling that she comes well prepared, that she is organized, that she knows what she is doing, what she is teaching. She has lots of knowledge and she knows what she has to teach.

Following the first interview with Neta, my impression was that she was a socially active teenager who possessed a high level of emotional intelligence [Journal].

\section{Sharon, the biology teacher}

Based on conversations I witnessed in the teachers' faculty room, I believed that Sharon's colleagues considered her to be intelligent and rational. She tried to do what her superiors expected of her and to conform with expectations [Journal].

The policy of this school comes from above and I just nod, say ok - and that's the way it goes.

She had been teaching in the current high school for 3 years and at the end of this year she was likely to be tenured.

Sharon always talked in a pleasant manner and with a smile on her face, even when the content of her words were unpleasant. When she told me that in the previous school year she had discussed with her principal the issue of being awarded tenure and was rejected, she referred to the matter with serenity, a smile, and using a relaxed tone of voice as if she had made peace with the fact that that was the way things were done at this high school - in spite of the fact that it clearly was not an easy topic for her to discuss [Journal].

Sharon projected optimism:

After all, it is clear that everything will work out in the end, right? 
Practicality

Well, if it has to be done, then let's get on with it.

At the same time, she tended to place high demands and standards on her students and she would calmly explain that she expected those demands and standards to be met. For example, on an occasion when she was teaching genetics and a student misbehaved she said:

\section{I, for example, have genes which may cause me to} ask a student to leave a lesson if he or she disrupts.

As mentioned earlier, during 9th grade the students choose in which subject(s) they wish to major. Some subjects have eligibility requirements. Sharon claimed that the goal of the biology teachers was to not allow mediocre students to choose biology as their major. Until then the best students almost always chose physics or chemistry while biology was viewed as the easiest scientific subject, so average students who wanted to have a science subject on their matriculation report typically chose biology. The biology teachers wanted to raise the status of biology by becoming more selective.

Me: "What about the students who like biology?"

Sharon: "What do you mean? There are eligibility

requirements...

\section{Mapping Neta's motivational characteristics}

At recess, Neta actively participated in conversations with her girlfriends. When the school bell rang, she advanced with some reluctance to the classroom, together with her girlfriends. However, upon entering the classroom, she sat at a table of her own, with no other classmate sitting next to her, at the second row from the teacher. When I asked her why she sat by herself, she demonstrates a high level of self-awareness and told me that this way it's easiest for her to engage in class and not be distracted [Journal].

At the beginning of the school year, Neta showed high personal mastery goals in science $\left(4.4^{1}\right)$, higher than most of her peers $(N=86)$ - see Fig. 2 - which increased to a very high value (4.8) near the end of the year - see Table 1. She showed a very high level of classroom engagement and the maximum possible level of selfefficacy in science (5.0) that decreased by the year's end. She had a lower level of personal performance-approach and avoidance goals than her peers. Neta perceived

\footnotetext{
${ }^{1}$ All ratings are on a scale of $1-5$.
}

Sharon's mastery and performance-avoidance emphases higher at the end of the year (4.3 and 2.0 respectively) than at the beginning (3.9 and 1.0 respectively). Neta consistently perceived her parent's mastery emphasis as very high (5.0) but lowered her perception of their performance emphasis over the year (2.5 at the beginning and 1.0 at the end).

Thus it seemed that despite a decrease in her selfefficacy, Neta remained strongly mastery oriented and slightly more aware, as we shall see later, of Sharon's performance-avoidance expectations.

The following excerpt is from an interview with Neta that was held near the beginning of the study:

Me: "How do you feel in Sharon's classes?"

Neta: "I feel good in her classes, Sharon often encourages me, she always gives me positive feedback, and it's good."

Me: "How do you feel with the material taught?"

Neta: "I feel alright, I have never had problems studying sciences, I get by."

Me: "Do you like studying the sciences?"

Neta: "Yes, I do not have problems studying the sciences."

Me: "Do you know what will be your major?"

Neta: "No, but I do know that it will definitely be a science."

Me: "So you are weighing between chemistry, physics and biology?"

Neta: "Yes."

Me: "And what do you think will determine your choice?

Neta: "I do not know. It very much depends on the teachers. I have a really good physics teacher; he is the best teacher in this school."

According to Bandura (1993), Neta's high sense of selfefficacy in science can be explained in several different ways. The first level is her previous performance accomplishments ("I have never had problems studying sciences"). The second level is verbal persuasion ("Sharon often encourages me". The third level is that of comparison to others (students tended to compare grades on 


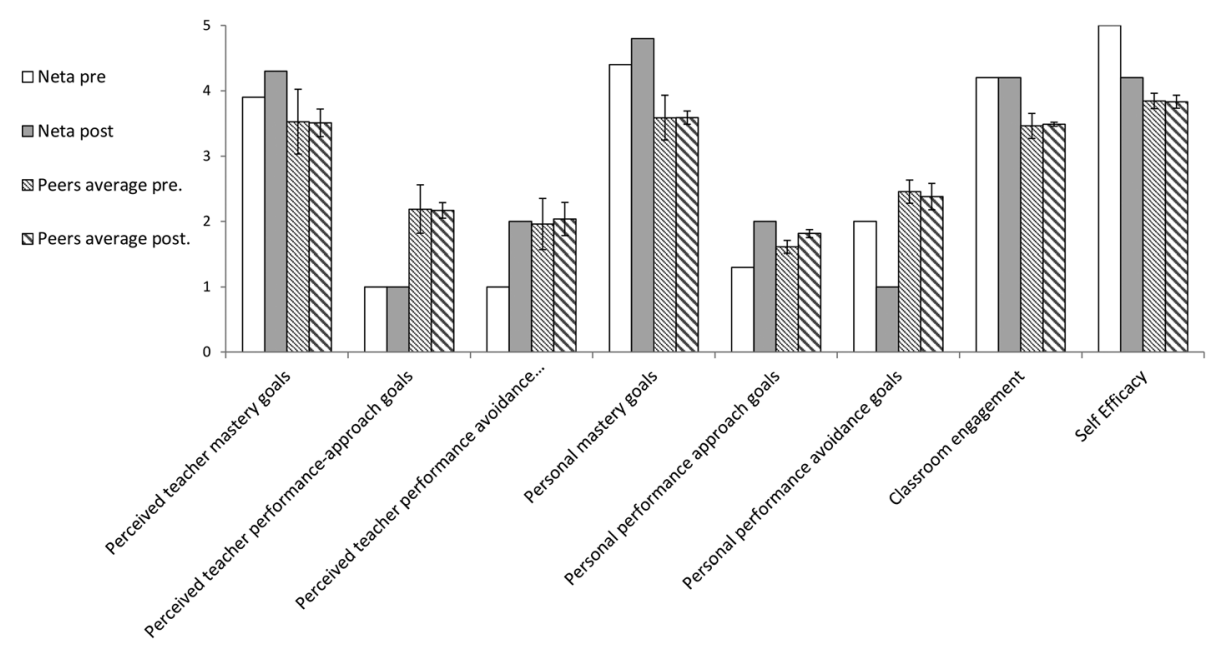

Fig. 2 Comparing Neta's Motivational Characteristics With Those of Her Classmates

assignments and Neta had scored above the class average on the first two quizzes).

\section{The disparity between Neta's achievements in biology and Sharon's perceptions of Neta}

Sharon described to me a conversation that she had had with the biology inspector from the ministry of education with regards to the school's plan to ease the load on the teachers who teach ninth graders. These were heterogeneous classes and over half the students had little motivation to learn biology. The plan was to send 5-6 of the "weakest" students to do self-work at the school's library instead of sitting in class:

Sharon: "It is likely that that will remove some of the students from the biology lessons, those who have no chance of continuing to study biology will do library work [during the biology lessons], but only those who do not disturb, so that they do not just experience a lack of success. This way they will not have to get tested in biology and the class will be ${ }^{2}$ smaller."

\section{Me: "Who, for example?"}

Sharon: "Yuval, Neta, Maayan..."

\footnotetext{
${ }^{2}$ According to the existing research literature, no consistency is found with regards to the influence of the class size on the accomplishments of students. Angrist and Lavy (1999) claimed that lowering the number of students who study in a classroom has a positive effect. On the other hand, a study done by Hanushek (1996) did not find such a positive effect. According to Pischke and Manning (2006) the influence of the heterogeneity of the class on the achievements of its students is even less clear, whereas Duflo, Dupas, and Kremer (2011) found that a great deal of class heterogeneity had a positive effect on the students.
}

\section{Me: "Neta Lustig?"}

Sharon: "She's so weak. It will only be for her own good."

I wonder: Is Neta really so weak that she is unable to distinguish between her ideal self and her realistic self? How can a student think so highly of her own abilities (self-efficacy $=5.0$, the highest possible value) yet be thought so weak by her teacher? I rechecked the students' grades and found that until then there had been two biology tests, on which Neta had obtained 92 and 93. According to Sharon, the second test was relatively difficult - the class averages were 83 and 79. Neta received the third highest grade in her class. So it appeared that it was Sharon rather than Neta who was misjudging Neta's abilities. What was the reason for Sharon's low appraisal of a student who was apparently talented, capable, and with high prior accomplishments in biology?

\section{Performance-avoidance in Sharon's classroom}

Neta appeared to consider her classroom a safe environment. Ruti (acronym), a friend of Neta who studied with her in the same classroom and had poorer achievements than Neta but was more highly appreciated by Sharon, said in an interview that Neta was not afraid of asking questions; when she didn't understand something, she didn't conceal the fact but expressed her lack of understanding, hoping to get it resolved. This aligned with Neta's extremely low performance-avoidance orientation (1.0, the lowest possible value) as assessed by the motivation survey.

I wondered - what does Sharon think about asking questions in class? 
Table 1 Neta's Motivation Questionnaire Scores ${ }^{a}$

\begin{tabular}{|c|c|c|c|c|}
\hline & Sep-13 & May-14 & Delta $^{b}$ & Reliabilityc \\
\hline Personal mastery goals & 4.4 & 4.8 & 0.4 & 0.87 \\
\hline Personal performance approach goals & 1.3 & 2.0 & 0.7 & 0.83 \\
\hline Personal performance avoidance goals & 2.0 & 1.0 & -1.0 & 0.79 \\
\hline Self-Efficacy & 5.0 & 4.2 & -0.8 & 0.86 \\
\hline Perceived science teacher's mastery emphasis & 3.9 & 4.3 & 0.4 & 0.83 \\
\hline Perceived teacher performance-approach goals & 1.0 & 1.0 & 0.0 & 0.74 \\
\hline Perceived teacher performance avoidance goals & 1.0 & 2.0 & 1.0 & 0.86 \\
\hline Perceived parents mastery emphasis & 5.0 & 5.0 & 0.0 & 0.73 \\
\hline Perceived parents performance emphasis & 2.5 & 1.0 & -1.5 & 0.80 \\
\hline Perceived peers mastery emphasis & 4.3 & 4.0 & -0.3 & 0.82 \\
\hline Perceived peers performance approach goals & 2.8 & 2.5 & -0.3 & 0.75 \\
\hline Perceived peers performance avoidance goals & 2.3 & 1.2 & -1.1 & 0.79 \\
\hline
\end{tabular}

All ratings are on a scale of $1-5$

${ }^{b}$ Delta is the difference between scores from May 14, 2013 and September 13, 2012

c The reliability of each scale is given by its Cronbach alpha

Me: "What kinds of questions would you say are legitimate to ask in the classroom?"

Sharon: "Well, in principle, any kind of question is legitimate, as long as it fits the time and the place."

Me: " "I don't understand"- is that a legitimate question?"

Sharon: "Depends! I may ask: what did you not understand? From what part of the explanation did you stop understanding? However, if the student asking is one who I know was absent from the lesson or does not pay attention, I may cut him or her off."

Me: "So you tell the student, if he or she were absent from the classroom that they have to make up what they missed?"

Sharon: "Yes, I will not hold up the entire class for a student who does not study - absolutely not, but you also have to get to know them. With some of them they have a habit of saying "I did not understand anything", and I will not answer those students in any case. With other students, I try to hold personal talks, and they also come on their own initiative to have personal talks with me. There are some students who ask questions which show that they understood nothing of what took place during the lesson. Quite often, I say: Not now, you are welcome to come and ask me during recess, but in 95\% of the cases - they do not come. I cannot afford to allow the lesson to deviate too much. I can, but I do not."
Me: "Are there some students whom you feel that had they not asked, you would have never known just how much they do not understand?"

Sharon: "Of course! On the contrary, their questions, I am glad that they ask, I am really happy that my classroom has an atmosphere which allows the students to ask questions.

Me: "As a student, which questions would you never have dared to ask?"

Sharon: "A question which implied that there was something I did not understand."

Me: "OK, and do you feel that there are students who feel free to ask exactly these kinds of questions?"

Sharon: "Sure."

Me: "And what do you think of them?"

Sharon: "Way to go! Way to go for them that they dare... As far as I am concerned, a student who participates receives a positive star by his name, and there is no such thing as a student who never understands anything. Of course, when I was a student, I did not realize that, but I was unable to evaluate how often I participated in a manner which positively $^{1}$ contributed to the class and proved ${ }^{2}$ my knowledge vs. the few ${ }^{3}$ cases that may ${ }^{4}$ have shown that I did not understand. By the way, I would not always ${ }^{5}$ ask, and there were situations when I would ask, if I had seen that there were several other 
students who did not ${ }^{6}$ understand, I would feel there was whispering in the classroom and then I would ask, when I was certain ${ }^{7}$ that it was legitimate ${ }^{8}$. But well, to sum up, I have a great appreciation of students who ask questions."

Despite Sharon's declaration that she was very happy when students asked questions in her classroom, and that as far she was concerned, every sort of participation was positive, her use of the phrase "dare to ask" and her recollections of her own attitude as a student about asking question in class $\left({ }^{1-8}\right)$ showed ambivalence on this issue. In the observations I made in Sharon's classes, it was my impression that Sharon usually didn't pay attention to the questions of her students. Her reactions to their questions may have been categorized as follows:

(1) Ignoring them

(2) Postponing: "You will study this in $11^{\text {th }}$ grade" or "We will return to your question later" (without actually returning to it), or "Come to me at recess, because it is not related to the lesson."

(3) Providing a brief or one-word answer.

(4) Providing a full answer.

An analysis of four 90-min lessons showed that, out of 111 questions asked of Sharon, she responded fully 18 times, gave a brief, one-word answer 21 times, ignored the question 52 times and postponed the response without returning to it 20 times.

van Zee, Iwasyk, Kurose, Simpson, and Wild (2001) pointed out a number of factors which enhance students' questioning including: comfortable discursive classroom norms, encouragement by the teacher to ask questions, subject matter with which the students have acquired some familiarity, and small group collaborative work. Dillon (1981) considers social considerations to be the most important factor. According to Watts, Alsop, Gould, and Walsh (1997), "asking questions can generate exposure and vulnerability. Learners need to feel secure before they risk an important question."

It appears that Sharon vacillated between beliefs that are "politically correct" and were drawn from ideas she learned while studying to become a teacher and other deeper beliefs that were based on her personal experiences as a student. On one hand, Sharon wished to provide the students with a secure atmosphere in the classroom in which everybody was encouraged to ask questions and instruction was guided by the students' questions. On the other hand, it appeared that her behavior was driven by a deeper, personal foundation, in which she was unable to identify with students who asked questions if they did not provide what she saw as a positive contribution and a demonstration of their knowledge. Sharon had difficulty identifying with a student who asked spontaneous (in her mind, thoughtless) questions, and thus, if the student asked a question which did not contribute to the debate in class and did not demonstrate that he or she understood the topic she considered it likely that the student was not prepared for the lesson or was simply weak. It appears that this syllogism - (A) only weak students ask thoughtless questions, and (B) Neta asked (in Sharon's eyes) thoughtless questions, therefore $(C)$ Neta must have been a weak student - is what may have led Sharon to believe that Neta is a weak student.

Kagan, Pearson, and Welch (1966) claimed that impulsive students often tend to be perceived by their teachers as "lagging behind in school". This is because they tend to provide inaccurate responses due to their hastiness, not due to their lack of knowledge. Teachers sometimes provide feedback to impulsive students without congruence with reality (Steele, 1997), comparing them to an "ideal student" as perceived by the teacher or in accordance with pre-defined measures of behavior and performance.

\section{Neta is mastery oriented with little performance- avoidance}

I asked Neta about the asking of questions within Sharon's classroom:

Neta: "She is very focused on the material being studied, but it is a little irritating. Because she is so focused, so let's say that I asked a question which is only slightly related to the lesson, she does not answer my question. But like, say we are talking about genetics, and I ask a question concerning genetics, but not exactly about what she is to talking about, but rather on something else that is related which interests me, and she ignores me."

Me: "Do you ask a lot of questions in class?"

Neta: "Basically, I am a girl who asks a lot of questions, because I am curious. If I have a question, I will not calm down until I have asked it, and if my question does not get answered, it gets me pretty upset."

Me: "And when she does not answer you..."

Neta: "I get pretty upset. I get so upset, and at the end of the lesson she apologizes but says that she cannot discuss topics which do not have to do with the lesson." 
Me: "And if there are topics that interest you, can you go to ask her at the end of the lesson?"

Neta: "Yes, but when the lesson is done then there is recess..."

During all the interviews, Neta kept saying that understanding biology was more important to her than other things, such as the possibility that people would think she didn't understand. This fit with my perception of Neta as being strongly mastery oriented.

In another interview with Neta, I tried to understand what drove Neta to ask so many questions and what she believed was the result of her asking questions:

Neta: "If I do not understand something and I do not ask, I get sort of uneasy, so I have to ask!"

Me: "Before you ask, do you filter your questions? Like, do you think, maybe everyone knows the answer to this question and only I do not?"

Neta: "No, I absolutely do not do that. I don't care. Whatever I wish to ask, I ask, even if some people may think it is a stupid question, I never have a problem asking."

At the beginning of the year Neta scored 2 in 1-5 performance-avoidance scale, and by the end of that year received a 1 on 1-5 same scale, indicating a very low performance-avoidance orientation. She summed up her position regarding asking questions in the classroom:

"I have to have the option of asking what I want; I have to have a teacher whom I can ask what I wish to know and I don't want to have to think about what I ask, and how she will react, what she will do."

I wonder, how was it that Neta didn't realize that Sharon may have found her questions inappropriate? The answer to this may have been that Sharon never responded harshly, did not make "facial expressions" to her students, helping them notice that there was something wrong.

\section{Who can major in biology?}

From an interview with Sharon about the process of deciding who gets to major in biology:

Me: "And what would happen if someone with that kind [a negative type] of engagement wished to major in science?"
Sharon: "There is a minimum average grade that is required. By the way, we cannot really prevent any student from majoring in science, even if they have a grade of fifty in biology, providing the student and their parents really want them to get in. There is no legal way to block them. This means that if a student wishes to get tested in the Biology Matriculation Exams with a grade of forty, we have no legal way to prevent this, we can recommend that they study something else, we can also make things more difficult, but legally speaking, we cannot refuse to teach a student any particular subject."

Me: "So what do you do to try and keep such a student from studying biology?"

Sharon: "Discussions with the student, with their parents..."

Me: "What do you tell them in those discussions?"

Sharon: "We tell them that the child's grades are low, that she does not fit, that we do not believe she will succeed, that it is preferable for her to be in a place where she will be able to experience success, where she will be able to achieve a respectable matriculation report. However, if they insist, we are not allowed to do anything and we know that, so we try, but it does not always work, in hope that most of these students will either give up or naturally drop out..."

Me: "Assuming that you will continue teaching some of these students next school year, within the biology major, are there some students who you assume will want to major in biology but that you would prefer them not to be there?"

Sharon: "I am not thinking about that at the moment, they still have a full semester ahead of them, they are children, adolescents, they can go through an amazing process of development. I do not want to get in their way. There are some children I know that want to and I know that they do not fit and will not succeed."

I saw here a declaration vs. an inner feeling - Sharon knew that the right thing to do would be to allow the students to undergo a developmental process, while in reality she had already labeled each student and already foresaw the lack of success of certain students. These may all have become self-fulfilling prophecies.

Snyder (1974) claimed that our level of selfmonitoring affects the way we behave in different 
social situations. The impression that one makes on others is typically very important to people with a high level of self-monitoring, and thus they behave in accordance to the impression they wish to create. These persons' behavior is not consistent and it changes in various situations. On the other hand, people with low levels of self-monitoring usually act in accordance with their positions, feelings or moods, rather than in accordance with hints provided by their surroundings. These people are more consistent in their behavior and it is easier to more accurately predict the way that they will behave. As she fluctuated back and forth between acting on her instincts and doing what was "proper" and "correct", it appeared that Sharon had a high level of selfmonitoring.

Self-monitoring and performance-avoidance orientation play an important role in the story of Neta and Sharon. Indeed, they often go together (Pintrich \& DeGroot, 1990; Zimmerman, 1990). Sharon was highly self-monitored, performance-avoidance oriented, and would therefore never have dared to ask a question that showed she didn't understand something. Neta, on the other hand, was less self-monitoring and had a very low performance-avoidance orientation, and therefore had no problem at all doing just that.

\section{Will Neta be allowed to major in biology?}

In order to better understand the process of choosing whether to major in biology, and how it was actually done, I asked Sharon for her opinion about it:

Me: "Who do you believe will continue to study extended biology? May I see the list?"

Sharon: "Now, this is the list of who I believe will be able to fit the study path of extended biology. I am telling you, some of these requests are not good matches for biology but are here because there's no other subject in which to place them. Well, from the third ninth grade homeroom, Neta may want to, but she is weak... It will be sad, and of course, she will force her way in, which will be even sadder." (Sharon continued to talk about the other students on her list).

Me: "So, from the third ninth grade homeroom, who do you believe will want to major in biology and will not be able to?"

Sharon: "Sara Gardi [a pseudonym] and perhaps Neta Lustig, but you will see that we will have surprises. There are still four to five months left."
Me: "How are their grades?"

Sharon: "Their grades are not very low, which is why I say that they are likely to want to, and it is a problem in ninth grade. It is a problem, because they may be able to get in."

\section{Me: "And what do you think of Neta's abilities?"}

Sharon: "Neta has a problem. She has a strong will and is motivated, but she has got a problem, which is also slightly emotional, in my view, of pressure."

Me: "Where do you see this being exhibited?"

Sharon: "She has an almost obsessive need to always prove herself in anything that she can, she has to try and do anything to get my attention, otherwise she is unable to concentrate, and sometimes she loses her concentration, and then you can see that she has very high motivation, but behavior that is different by nearly one-hundred and eighty degrees."

Was it possible that as far as Sharon was concerned, Neta represented much of what she herself had wanted to be but could not and thus Neta actually served as a threat to Sharon's self-image?

Me: "So do you think the difference in her behavior derives from lack of self-control?

Sharon: "Exactly! And it is on the inside, she's a child who thinks very poorly of herself, there's a great burden on her, and you can see the impact on her that something that is not good is happening. Sometimes, there is something that she comes with to the classroom that is derived from someplace else. She is a girl whom I really find it necessary to strengthen. For example, it is clear to me, that she is 'crying out' to be complimented."

Me: "So now, what happens if she wants to major in biology?"

Sharon: "She will continue. We have no basis to stop her because it is likely that in other extended subjects she will have those same problems."

Sharon didn't keep her opinion about Neta entirely to herself, but shared it with Neta's entire classroom. During a demonstration in class, Sharon asked for a volunteer. Neta requested to be the volunteer and Sharon mocked her in front of her entire classroom and invited another volunteer. 
Sharon: "Who wants to say if the water is warm?"

Neta: "I do, I do!"

Sharon: "Do we trust Neta?"

A group of students: "No!!!" (Exploding laughter)

M.M. (another student): "I want to!" (Approaches and checks)

Despite this incident, Neta continued to be active and still asked questions when she did not understand.

In order to be able to address the incongruence between Neta's perception of her performance and the low appraisal she received from her teacher, I checked whether Sharon and Neta perceived the requirements for acceptance into biology in the same manner. So I asked Neta:

Me: "If I ask Sharon what kind of student you are, what will she say?"

Neta: "That I am a good student, although I am unable to achieve high grades. She has also told me that my behavior is really good, but my grades are not high enough. She sees that I am making an effort, but it is not enough. It really gets me down..."

How do I know that Sharon actually conveyed to Neta the thoughts that she reported to me? Or, perhaps she conveyed those thoughts to Neta, but Neta was unable to "hear" them?

\section{The beginning of a golem effect?}

Sharon defined Neta as a weak student. She suggested removing her from biology lessons altogether, along with a group of other weak students. She did not allow her to volunteer during a class experiment and did so very bluntly (“Do we trust Neta?"). Perhaps these low expectations were beginning to fulfill themselves...

Me: "How are things coming along in the biology lessons?"

Neta: "My grades in biology have deteriorated. At the beginning of the school year I had had a ninety average. My grades have really deteriorated and it upsets me, because I wish to major in biology."

At the beginning of the year, Neta received a 92 and a 93 in the first two biology tests. Her grades then decreased to 71,78 , and 63 .
Me: "So what do you have to do?"

Neta: "I have to work harder, but, uh..."

Me: "Are you working harder?"

Neta: "Yes."

Me: "And in spite of this, you have a seventysomething average?"

Neta: "Yes. Perhaps I need to work harder? But I don't know..."

I saw this statement as a sign that Neta was beginning to doubt her ability in biology.

Me: "Do you also have to work harder in other subjects as well?"

Neta: "No. My grades are high in the other subjects, and my report card was really good. But biology upsets me, because it is a subject that I really love studying, and I want to major in that subject, and my grades are not good enough, and it puts me behind."

Me: "What do you intend to do if you are unable to improve your grades?"

Neta: "I will keep trying, and if not, then I will have to think of another extended subject to study. I'll make an effort, but if I do not succeed..."

It seemed that Neta grasped that the system would make things difficult for her in biology. She did not doubt her desire to study extended biology, but her grades, which were lower than in other subjects and the feedback she received from Sharon, were raising concerns about her ability to be accepted to and succeed in biology.

\section{Me: "How do you define 'not being successful'?"}

Neta: "If I am told that my average is not high enough. I do not know what average is needed for biology. This semester I received an eighty in biology and I do not know if it is enough".

Neta obtained an 81 and it is quite enough.

Neta's grades seem to have been affected, but Neta distinguished between her biology achievements and her achievements in other subjects. Her self-esteem was still high, but she was aware of her disadvantage in biology. She blamed herself for it and offered a solution that was entirely dependent on her. 
Figure 3 presents Neta's grades in biology from the beginning of the year till the end of the first semester:

The graph clearly shows the deterioration in Neta's grades from the beginning of the school year to the end of the first semester. It may just be a coincidence, but Neta's lowest grade was obtained in a quiz on the digestion system, which was the very topic of the experiment in which Neta was "banned" from volunteering. In other words, it is possible, that Sharon's treatment of Neta affected her subconsciously.

\section{Clashing perspectives on learning in biology class}

Sharon talked to me about Neta, and particularly about the manner in which she participated in the classroom. According to Sharon, Neta's participation did not demonstrate her knowledge, nor did she contribute to the class discussion.

"Sometimes she is really annoying, she doesn't... she has a little something about her... She does not understand her environment. I might say something, and although she is a very attentive student, she may very well pose a question to which I had just given an answer! And this can happen three times during the same lesson!

"Now, each lesson I must repeat it all again. Twice a lesson - fine, but the third time drives me crazy! In the last lesson she was offended, and said to me, 'Alright, you do not have to get mad at me...' I told her: 'Listen, I am not mad at you and I had had no intention of insulting you, but you know, try to think a second before you ask. I am not telling you not to ask, I am just asking you to think a little... Ok, we have made up".
It appears that Sharon could not allow herself to say, "Do not ask unless it is a smart question, which will make me think that you understand", because she knew that that was inappropriate. However, in essence, this is exactly what she expected. This is the essence of "performance-avoidance".

Neta mentioned the exact same situation in one of the interviews. She said:

"There was one time when I raised my hand and asked a question, and she said: 'I am answering this very question right now' and then I made faces during the rest of the lesson. At the end of the lesson, she approached me and said she was sorry and that she does not want to fight with me, but that what I was asking was unrelated to the lesson and she did not want to deviate from the topic of the lesson".

The situation was a genetics lesson concerning Mendel's theory. Sharon had given an example concerning a white mouse and a black mouse. One of the students had asked a general question regarding the color of hair and Sharon had asked that in order to keep focused on the concepts, which were very complicated, the class should not ask questions not relating to the particular example. Ten minutes later, Neta asked a question about the color of the eyes, which irritated Sharon, as she had specifically asked the class not to ask questions which were unrelated to the example.

According to the motivation survey she completed, Sharon perceived herself as possessing a high level of expertise as well as being very performance-approach oriented, that is, she wanted others to recognize her high level of expertise. This was very clear to the students,

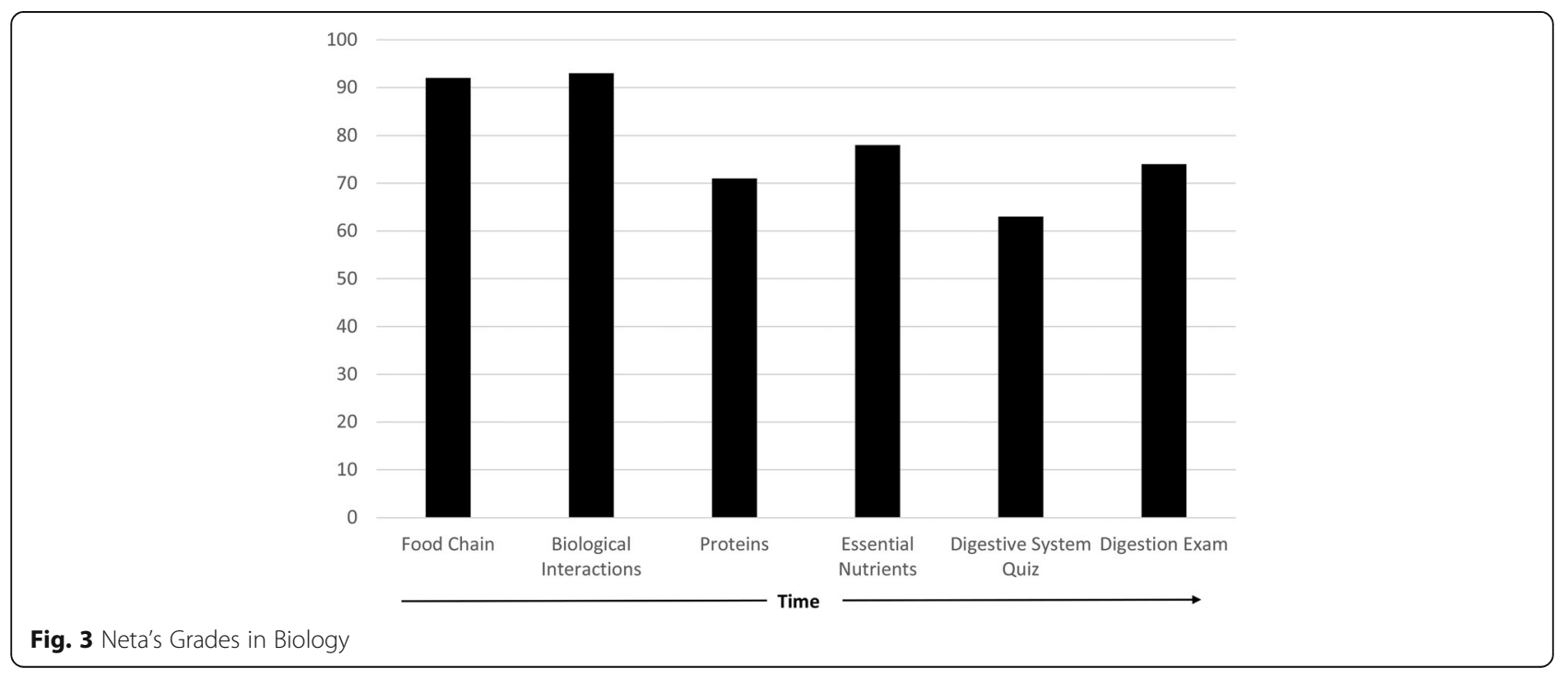


as was shown in an interview with Noga Kaplan (pseudonym) (an outstanding student in a parallel ninth grade class):

Me: "Had Sharon been a student in your classroom, what type of student would she be?"

Noga: "I think she would be one of the outstanding students, who really like to show it. I also think that she teaches in a manner of 'I know the material, listen to me, be quiet, I know what I am doing'. That is her preferred teaching style."

Sharon's conception of Neta, whom she perceived to be a failing student, was derived from the way Neta participated in her class. Sharon concluded that Neta's ability was low due to the fact that she was more impulsive than reflective. An example of Neta's impulsiveness (rather than reflectivity) may be seen in an interview with her, which was held during the beginning of the second semester:

"I do not know why I am unsuccessful in achieving high grades. In other subjects I am successful. I do not know what it is about biology that prevents me from succeeding. Perhaps it has to do with Sharon's tests, which are basically not difficult, so it is possible that I do the tests too quickly, without thinking thoroughly. I think I am just excited about knowing everything."

Neta, in an interview held after the second semester:

"Sharon keeps telling us that if our current grades are not high, then next year they will be even lower, so that's it... I saw that my grades are not good, so I decided to major in biology only if my grades get better, but when I saw that they were not getting better, I decided I will major in biology anyway, because biology interests me and I want to invest my efforts in it.

When I came to Sharon to ask her regarding biology... yes, I now recall having cried a lot. I had my choice of extended studies and I said I wished to study biology. So I asked Sharon, 'What do you think about my studying biology?' and she said, 'No, I do not believe it suits you'. So I asked her, 'Why?' and she said, 'I am sorry, but your grades are not high enough.' I felt so helpless and I just began crying, I felt lost, as if she was telling me that I am unable to study any of those subjects..."

Me: "In your opinion, why did she tell you that?"
Neta: "She was advising me not to study it. She said that biology is a demanding subject and it will be too difficult for me to keep up, that it just gets more and more difficult.

Me: "What did you feel?"

Neta: "I felt a little insulted because I do participate a lot in class and answer all of the questions that Sharon asks. I mean, I always have explanations... So I was a little offended."

\section{What enabled Neta to resist Sharon's recommendation?}

So how was it possible that the negative messages conveyed by Sharon did not break Neta's spirit and prevent her from choosing to major in biology?

Me: "From one to five, to what extent did this year's studies help you choose to major in biology rather than another subject?"

Neta: "The studies!! I enjoyed the biology lessons. It's not as if I had come here and said, 'I'll take biology...'

Me: "Did your parents also assist you in choosing to major in biology?"

Neta: "We discussed it, and my parents said, 'Don't let your teacher get to you; if it is really what you want, go for it'; they told me to study what interests me, that it was basically my decision."

Me: "So your decision had had nothing to do with your teacher or your parents?"

Neta: "My parents preferred that I study physics. I had also at one stage wanted to study physics. But I chose to study biology and they supported my decision."

Me: "What would you have chosen had none of your friends chosen to major in biology?"

Neta: "I chose to major in parallel also in philosophy, even though none of my friends chose to study it, and I don't care. Regardless of the fact that most of the students in my grade chose to major in biology, my friends were not a consideration."

Me: "If I asked you to grade the following according to their level of importance, how would you choose 
to grade them: What interests you, parents, friends and teachers?

Neta: "What interests me, teachers, parents and then friends."

Neta was intrinsically mastery oriented. She learned because she wanted to, because it interested her. Her parents supported this mastery orientation. Neta shared with her parents the feelings of uncertainty she had following the conversation she held with Sharon with regards to choosing in which subjects to major. Neta's parents encouraged her to follow her heart's desire.

According to Rogers and Koch (1959), every person has a basic need of positive evaluation, respect, love and acceptance from his or her significant others, and the important thing is the way a person perceives the way he is treated by his parents (as opposed to the objective reality). This is the most important foundation for proper development. Children who experience a positive, unconditional positive appraisal develop positive selfimages, which allow them to act in accordance with their own beliefs, without fearing obstacles that may lie in the way of their self-fulfillment.

Neta said of her relations with her mother: "My mother knows everything about me...she supports be completely." It appears that Neta's parents trusted her, provided her with autonomy, accepted her and her decisions, and actually served as encouraging partners in her life. Neta was strengthened by them and her selfconfidence was reinforced by them. This enabled her maintain her belief in herself and follow her interests and her mastery orientation in spite of the negative messages she received from Sharon. She chose to major in biology in spite of Sharon's attempt to convince her that it is for her own good to choose a less demanding extended matriculation path.

\section{Discussion}

This study described a case of a how differences in a science teacher and her student's achievement goal orientations created tensions between their perspectives of what it meant to do school science, leading the teacher to under-estimate the student and recommend that she abandon further studied in biology. Following the teacher's criticism and negative feedback (Koballa, 1992), the student's self-efficacy and grades in biology dropped, but not enough to overcome her strong mastery orientation; she persisted to love biology and chose to major in the subject (Hazari, Sonnert, Sadler, \& Shanahan, 2010). While researchers have used expectancy-value theory (Eccles et al., 1983; Eden, 1986) to explain the mechanism through which under-estimation can lead to a lower sense of self-efficacy and lower performance, the reasons why a science teacher may under-estimate a student and why a student may be able to the negative influence of under-estimation has yet to be studied. As demonstrated, we believe that achievement goal orientations may play a major role in explaining these two phenomena.

In the current study we followed the relationship between a student with high mastery goals and very low performance-avoidance goals and her high mastery and high performance-avoidance goals oriented biology teacher.

The student was a "victim" of her own goals. Being highly mastery oriented, she wanted to really understand what her biology teacher was saying, and she asked many questions in class. However, being also very low performance-avoidance oriented, some of her questions were asked impulsively, without thinking them through or considering whether they were "appropriate", according to the teacher's definition. The biology teacher, being highly performance-avoidance oriented, couldn't see beyond the apparent thoughtlessness of some of the student's questions, couldn't understand or identify with the low performance-avoidance goals orientation of her student, categorized the student as very weak and had low expectations of her. Being also highly mastery oriented, the biology teacher viewed the student as not being suited to learn a demanding subject like biology or any other science.

Our findings support other studies (e.g., Brophy, 1983) that indicated that a students' sense of self-efficacy and level of achievement can decrease due to low expectations of the teacher. This study adds to the literature by providing a rich description of the relationship between a student and teacher, their opinions of one another and of themselves, and by suggesting an explanation, based on achievement goals orientation theory, for the reasons the teacher perceived the student as she did and how this perception led to the student's decline. Furthermore, this study also shows how, due to her strong mastery orientation and interest in biology, and with the support of parents who were perceived by the students as supportive and mastery-oriented, the student was able to remain true to her interests and desires, prevent her sense of self-efficacy in biology from falling too much, reject her teacher's negative recommendations and choose to major in biology. Thus, in the case of this highly mastery oriented student, the major influence on her decision in what to major was her own desire, with three significant adults in her life (her parents and the biology teacher) respectively supporting or rejecting her personal desire and her personal sense of self-efficacy.

We wonder how many other capable students like Neta there are there who, had they be given the opportunity by their teachers, might have chosen to major in 
science? When looking for ways to increase the number of students who choose to major in science, shouldn't we start by supporting students who want to major in science to actually do so?

\section{Conclusion}

Hopefully this study will encourage readers, teachers and researchers, to reflect on their own achievement goals orientations goals and think twice, before advising their students what is "best for them", be they adolescents or university students. We all want classrooms in which students feel comfortable to express themselves freely, ask questions, describe what they think and feel even though it may not be aligned with our goals. It is known from prior studies (Gonida, Kiosseoglou, \& Voulala, 2007; Maehr, 1991; Vedder-Weiss \& Fortus, 2013) that as students mature, teachers typically become the most significant adult in the students' academic lives and that the teacher's goals emphases are directly related to student's achievement goals orientations, with this relation strengthening as the student matures. The goals emphases that teachers broadcast to their students are important and can make a difference. We believe it's important for teachers to have a mapping of their students' achievement goals orientations when making recommendations about their student academic lives.

This study can help us realize the importance of being aware of our own achievement goals orientation, be we teachers, students or researchers, and possible interactions between different orientations. As teacher we should consider in which ways we might be sending to our students explicit or implicit messages of performance-avoidance? We wonder whether the achievement goals orientations of adults are malleable enough to be changed. Could learning about achievement goals orientations in pre-service and in-service courses, and then working with teachers to identify their own orientations and from them the possible ramification of these goals for their students, help teachers develop a more mastery-centered orientation?

\section{Afterword}

Two years later, Neta was doing very well in the extended biology track (according to her new biology teacher) and was greatly interest in the curriculum:

"Biology is the most interesting lesson I've got, except for philosophy, it's everything, it is life ... everything!"

Neta still remembered her feelings in 9th grade. I asked her what she thinks was the issue between Sharon and her:
"I don't really know, I think she simply didn't like me, maybe she thought I was a bad student. Luckily my mom told me that whatever Sharon told me was nonsense and that if I wanted to choose biology I should do so, that she was sure that I would do well. Luckily I listened to her ..."

\section{Supplementary information}

Supplementary information accompanies this paper at https://doi.org/10 1186/s43031-020-00023-6.

Additional file 1. Online Supplement S1.

Additional file 2. Supplement S2. Example Items from the Various Scales.

\section{Abbreviations}

AP: Advanced Placement; IRB: Institutional Review Board; IQ: Intelligence Quotient

Authors' contributions

Both authors contributed equally to the study. The author(s) read and approved the final manuscript.

Author's information

Fortus is the Chief Justice Bora Laskin Professorial Chair of Science Teaching.

Funding

No external funding was received for this study.

Availability of data and materials

Not applicable.

Ethics approval and consent to participate

Approval to conduct this study was given by the Office of the Chief Scientist of the Israeli Ministry of Education.

Consent for publication

Not applicable.

Competing interests

Neither one of the authors has any competing financial or non-financial interests.

Received: 7 December 2019 Accepted: 27 March 2020

Published online: 14 May 2020

\section{References}

Ames, C. (1992). Classrooms: Goals, structures, and student motivation. Journal of Educational Psychology, 84, 261-271

Angrist, J. D., \& Lavy, V. (1999). Using Maimonides' rule to estimate the effect of class size on scholastic achievement. Quarterly Journal of Economics (114), 533-575.

Babad, E. Y., Inbar, J., \& Rosenthal, R. (1982). Pygmalion, Galatea, and the golem: Investigations of biased and unbiased teachers. Journal of Educational Psychology, 74(4), 459.

Bandura, A. (1993). Perceived self-efficacy in cognitive development and functioning. Educational Psychologist, 28(2), 117-148.

Bandura, A. (1994). Self-efficacy. In V. S. Ramachaudran (Ed.), Encyclopedia of human behavior, (vol. 4, pp. 71-81). New York: Academic Press.

Basu, S. J., \& Barton, A. C. (2007). Developing a sustained interest in science among urban minority youth. Journal of Research in Science Teaching, 44(3), 466-489.

Beghetto, R. A. (2007). Factors associated with middle and secondary students' perceived science competence. Journal of Research in Science Teaching, 44(6), 800-814.

Brophy, J. E. (1983). Research on the self-fulfilling prophecy and teacher expectations. Journal of Educational Psychology, 75(5), 631. 
Clandinin, D. J. (2006). Narrative inquiry: A methodology for studying lived experience. Research Studies in Music Education, 27(1), 44-54.

Connelly, F. M., \& Clandinin, D. J. (1990). Stories of experience and narrative inquiry. Educational Researcher, 19(5), 2-14.

Dillon, J. T. (1981). Duration of response to teacher questions and statements. Contemporary Educational Psychology, 6(1), 1-11.

Duflo, E., Dupas, P., \& Kremer, M. (2011). Peer effects, teacher incentives, and the impact of tracking: Evidence from a randomized evaluation in Kenya. American Economic Review 101(5), 1739-1774.

Eccles, J. S., Adler, T. F., Futterman, R., Goff, S. B., Kaczala, C. M., Meece, J. L., \& Midgley, C. (1983). Expectancies, values, and academic behaviors. In J. T. Spence (Ed.), Achievement and achievement motivation, (pp. 75-146). San Francisco, CA: W. H. Freeman.

Eden, D. (1986). OD and self-fulfilling prophecy: Boosting productivity by raising expectations. The Journal of Applied Behavioral Science, 22(1), 1-13.

Fortus, D., \& Daphna, L. (2017). Adolescents' goal orientations for science in single-gender Israeli religious schools. International Journal of Science Education, 39(1), 86-103.

Fortus, D., \& Vedder-Weiss, D. (2014). Measuring students continuing motivation for science learning. Journal of Research in Science Teaching, 51(4), 497-522.

Friedel, J. M., Cortina, K. S., Turner, J. C., \& Midgley, C. (2007). Achievement goals, efficacy beliefs and coping strategies in mathematics: The roles of perceived parent and teacher goal emphases. Contemporary Educational Psychology, 32(3), 434-458.

Gonida, E. N., Kiosseoglou, G., \& Voulala, K. (2007). Perceptions of parent goals and their contribution to student achievement goal orientation and engagement in the classroom: Grade-level differences across adolescence. European Journal of Psychology of Education, 22(1), 23-39.

Hanushek, E. A. (1996). A more complete picture of school resource policies. Review of Educational Research 66(3), 397-409.

Hazari, Z., Sonnert, G., Sadler, P. M., \& Shanahan, M.-C. (2010). Connecting high school physics experiences, outcome expectations, physics identity, and physics career choice: A gender study. Journal of Research in Science Teaching, 47(8), 978-1003.

Israel Central Bureau of Statistics. (2012). The face of society in Israel. Retrieved from http://www.cbs.gov.il/webpub/pub/text_page.html?publ=54\&CYear= 2010\&CMonth=1

Jamieson, D. W., Lydon, J. E., Stewart, G., \& Zanna, M. P. (1987). Pygmalion revisited: New evidence for student expectancy effects in the classroom. Journal of Educational Psychology, 79(4), 461.

Kagan, J., Pearson, L., \& Welch, L. (1966). Conceptual impulsivity and inductive reasoning. Child Development, 37(3), 583-594.

Koballa, T. R. (1992). Persuasion and attitude change in science education. Journal of Research in Science Teaching, 29(1), 63-80. https://doi.org/10.1002/tea. 3660290107.

Maehr, M. L. (1991). The "psychological environment" of the school: A focus for school leadership. In P. Thurstone, \& P. Zodhiates (Eds.), Advances in Educational Administration (Vol. 2: School leadership, (pp. 51-81). Greenwich: JAl Press.

Meece, J. L., Blumenfeld, P. C., \& Hoyle, R. H. (1988). Students' goal orientations and cognitive engagement in classroom activities. Jounal of Educational Psychology, 80(4), 514-523

Meis Friedrichsen, P., \& Dana, T. M. (2005). Substantive-level theory of highly regarded secondary biology teachers' science teaching orientations. Journal of Research in Science Teaching, 42(2), 218-244. https://doi.org/10.1002/tea.20046.

Murphy, D., Campbell, C., \& Garavan, T. N. (1999). The Pygmalion effect reconsidered: Its implications for education, training and workplace learning. Journal of European Industrial Training. 23(4/5):238-251.

Pajares, F., \& Graham, L. (1999). Self-efficacy, motivation constructs, and mathematics performance of entering middle school students. Contemporary Educational Psychology, 24(2), 124-139.

Pintrich, P. R., \& DeGroot, E. V. (1990). Motivational and self-regulated learning components of classroom academic performance. Journal of Educational Psychology, 82, 33-40.

Pischke, J. S., \& Manning, A. (2006). Comprehensive versus selective schooling in England in Wales: What do we know? (No. w12176). National Bureau of Economic Research.

Reynolds, D. (2007). Restraining golem and harnessing Pygmalion in the classroom: A laboratory study of managerial expectations and task design. Academy of Management Learning \& Education, 6(4), 475-483.
Rogers, C. R., \& Koch, S. (1959). A theory of therapy, personality, and interpersonal relationships: As developed in the client-centered framework.

Rosenthal, R., \& Jacobson, L. (1968). Pygmalion in the classroom: Teacher expectation and pupils' intellectual development. Holt: Rinehart \& Winston.

Senko, C., Hulleman, C. S., \& Harackiewicz, J. M. (2011). Achievement goal theory at the crossroads: Old controversies, current challenges, and new directions. Educational Psychologist, 46(1), 26-47.

Snyder, M. (1974). Self-monitoring of expressive behavior. Journal of Personality and Social Psychology, 30(4), 526.

Stake, R. E. (1995). The art of case study. Thousand Oaks: Sage.

Steele, C. M. (1997). A threat in the air: How stereotypes shape intellectual identity and performance. American Psychologist, 52(6), 613.

Strauss, A. L., \& Corbin, J. M. (1990). Basics of qualitative research, (vol. 15). Newbury Park: Sage.

Thody, A. (2006). Writing and presenting research. London: SAGE Publications.

Usher, E. L., \& Pajares, F. (2008). Sources of self-efficacy in school: Critical review of the literature and future directions. Review of Educational Research, 78(4), 751-796.

van Zee, E. H., Iwasyk, M., Kurose, A., Simpson, D., \& Wild, J. (2001). Student and teacher questioning during conversations about science. Journal of Research in Science Teaching, 38(2), 159-190.

Vedder-Weiss, D., \& Fortus, D. (2011). Adolescents' declining motivation to learn science: Inevitable or not? Journal of Research in Science Teaching, 48(2), 199 216.

Vedder-Weiss, D., \& Fortus, D. (2012). Students' declining motivation to learn science: A follow up study. Journal of Research in Science Teaching, 49(9), 1057-1095.

Vedder-Weiss, D., \& Fortus, D. (2013). School, teacher, peers and parents' goals emphases and adolescents' motivation to learn science in and out of school. Journal of Research in Science Teaching, 50(8), 952-988.

Watts, M., Alsop, S., Gould, G., \& Walsh, A. (1997). Prompting teachers' constructive reflection: Pupils' questions as critical incidents. International Journal of Science Education, 19(9), 1025-1037.

Zepeda, C. D., Richey, J. E., Ronevich, P., \& Nokes-Malach, T. J. (2015). Direct instruction of metacognition benefits adolescent science learning, transfer, and motivation: An in vivo study. Journal of Educational Psychology, 107(4), 954-970. https://doi.org/10.1037/edu0000022.

Zimmerman, B. J. (1990). Self-regulated learning and academic achievement: An overview. Educational Psychologist, 25(1), 3-17.

\section{Publisher's Note}

Springer Nature remains neutral with regard to jurisdictional claims in published maps and institutional affiliations.

\section{Submit your manuscript to a SpringerOpen ${ }^{\circ}$ journal and benefit from:}

- Convenient online submission

- Rigorous peer review

- Open access: articles freely available online

- High visibility within the field

- Retaining the copyright to your article

Submit your next manuscript at $\boldsymbol{\nabla}$ springeropen.com 